\title{
European Union Market Access Conditions and Africa's Extensive Margin of Food Trade
}

\author{
Fatima Olanike Kareem ${ }^{a}$ \\ Bernhard Brümmer \\ Inmaculada Martinez-Zarzoso ${ }^{\mathrm{c}}$
}

\begin{abstract}
${ }^{a}$ Corresponding author, Research Associate, GlobalFood Research Training Group 1666, Heinrich DukerWeg 12, 37073 Goettingen, University of Goettingen, Germany. Email: fkareem@ uni-goettingen.de. Phone: +49 55139 20215

bProfessor, Department of Agricultural Economics, University of Goettingen, Platz der Goettinger Sieben 5, D37073 Goettingen, Germany.Email: bbruemm@gwdg.de

'Professor, Department of Economics and Center for Statistics, University of Goettingen, Platz der Goettinger Sieben 3, 37073 Goettingen, Germany Email: martinei@uji.es
\end{abstract}

\section{Introduction}

The last decades have witness a structural shift from the exports of traditional agricultural food products such as cocoa and sugar by most developing countries to non-traditional high value agricultural food products such processed and fresh fruits and vegetables (Reardon et al, 2009). Thus, trade is increasingly playing a significant role in the provision of food, export earnings and economic growth for many developing countries. However, this cannot be categorically said for Africa countries, many of who have gradually become predominant net food importers (World Bank, 2012). In addition, the continent continues to depend majorly on exports of traditional valued agricultural-food products despite the structural shift of most developing countries to non-traditional high value agricultural. Consequently, this may jeopardise the significant role played by food export in stimulating economic growth and as a means of poverty reduction especially for sub-Saharan African countries many of which depend heavily on agriculture for sustenance. This weak integration of most African countries into global economy can be an impediment to the developmental progress of the continent, majorly because deep trade integration is widely viewed as the most promising avenue to achieving economic growth (Nicita and Rollo, 2015).

Numerous factors have been linked to the weak integration of African countries in global markets and these include high cost of exporting and poorly developed trade facilitation infrastructure (Djankov, Freund, and Pham, 2010; and Iwanow and Kirkpatrick, 2009 and Portugal-Perez and Wilson, 2012), domestic supply constraints (Xiong and Beghin, 2012) and trade inhibiting non-tariff barriers imposed on its exports (Shephard and Wilson, 2013, Otsuki et al., 2001). Of these obstacles, non-tariff barriers (NTBs) have been identified as the single most important market access condition for Africa's exports (Czubala et al, 2009), thus necessitating a careful study of it. Consequently, a better understanding of the actual impacts/implications of such NTBs for market access is of paramount importance for the continent majority of who depend on agricultural activities for livelihood. 
The purpose of this study is to investigate the impact of two important non-tariff regulations imposed by the EU on Africa's food exports. The first is food safety standard which has gained in importance in recent years due to a number of food scares in developed countries (UnNeverhr, 2003). This makes standards to constitute one of the most important market access conditions imposed by the EU on food exports. Standard is of particular concern to exporters due to its dual ability to be used as protectionist measure in preventing imports and its legitimate use for the protection of consumers' health and safety. On the one hand, there is the 'standards as barrier' perspective where standard has been viewed as a barrier to export penetration due to its trade costs effects. The proposition is that standards affect trade competitiveness because meeting stringent standards imposes excessive costs of compliance borne by the producers which might erode export competitiveness and affect the profitability of the export product, thereby acting as a barrier to trade (Markus and Wilson, 2001). In addition, the increasing stringency of these standards implies rising cost of compliance. Higher compliance costs for developing countries discourages potential exporters from penetrating foreign markets, drive less productive firms away from international market, decreases both the trade volume and sustainability of the remaining exporters (Bao and Chen, 2013). The situation is aggravated for exporters from Africa due to their lack of necessary infrastructure and technology which inhibit their ability to comply with importing countries standards. However, standards can also be trade enhancing once the right set of environment is set up (Jaffee and Henson, 2004). On the one hand, the view of standards as a catalyst to trade argument is in line with the demand enhancing effects of standards. According to this stance, standards help in building value into certified goods and services as it provide consumers with information and assurance about their health and safety, therefore stimulating import demand (Moenius, 2004). Standards also remedy asymmetric information, providing information to producers about the specifications and technicalities of the products, which can lead to technology diffusion and innovation (Baller, 2007).

A second but usually neglected market access condition that exporters face when exporting fresh fruits and vegetable to the EU is the EU entry price control. This measure aims to protect EU growers of 15 fruits and vegetable products from international competition by the imposition of a minimum entry price requirement. This non-tariff measure acts to restrict the synthetic import prices below the predetermined entry price, and lead to the imposition of a specific duty on exports, when the import price falls below a predetermined minimum entry price. This therefore erodes the export competitiveness while increasing EU growers' competitiveness relative to exporters'. This system of protection is known as the EU entry price system (thereafter EPS) and it is imposed simultaneously with the EU safety standards.

This study therefore investigates the implications of EU entry price conditions and safety standards on Africa's exports, on the probability of initiating new export relationship with the EU (the extensive margin ${ }^{1}$ of trade). We investigated the impact within a gravity model using panel dataset between 2008 and 2013 focusing on the fresh fruits and vegetables exports namely tomatoes, oranges, lime and lemons. The choice of the export products is due to the fact that they are simultaneously subjected to EU entry price control and also attract stringent pesticides regulations due to their perishability nature and susceptibility to food safety risks. In

\footnotetext{
${ }^{1}$ Export expansion at the extensive margin implies, selling new products to new markets, selling new products to existing markets, selling exiting products to new markets. However, in this paper, the concept of extensive margin is used in the context of selling existing products to new markets.
} 
our analysis, we investigated the potential impacts of food safety standards on Africa's export, using EU food safety regulations on allowable pesticide residues in food. Although EU food safety standard regulations encompass many requirements, all of which needed to be satisfied, however, the focus of this study is on pesticide standards. Out of all EU food safety requirements, the violation of the acceptable maximum residual limits (MRL) of pesticides in food or feed products represents the second largest reason for border rejections of third country's exports to the EU, which consequently constitutes loss of export revenue and products to the exporters. In fact, the violations of pesticide residue limits constitute about $70 \%$ of EU rejection of all Africa's fruits and vegetable exports between 2008 and 2013, thus indicating an important market access problem (EC RASFF, 2014).

This study is motivated by the recent literature on firm heterogeneity which reveal that the growth of developing countries trade was predominantly due to the expansion of trade along the extensive margin rather than due to growth in the volume of trade (Reis and Farole, 2012; Nicita and Roll, 2015). In spite of this assertion, we argue that the ability of African countries to initiate or penetrate new markets might be ultimately constrained by stringent importing countries market conditions. Thus, the analysis of aforementioned EU market conditions in the food sector on Africa's along the extensive margin is crucial to understand the process of entry and exist in export markets and also identify which factor may be the biggest constraint to Africa's export competiveness. For instance, studies that look at the impact of EU market conditions in the food sector on Africa's exports has predominantly focus on the intensive margin (Otsuki, et al., 2001; Grebrehewit et al., 2007). However, the implications of EU food regulations have received less attention on market access at the extensive margin of trade. Having a better understanding of the effects of these two EU market access conditions in the food sector and its effects on potential exporters is therefore important from a policy perspective.

The remainder of this paper is organized as follows. Section 2 provides background information on the two EU market access conditions. Section 3 assesses the extent to which the two market access conditions affect Africa export's competitiveness. Section 4 discusses the methodology and the data. Section 5 discusses the results and the final section concludes.

\section{Market Access Requirements in EU Food Sector}

This section provides background information on the two important and complementary nontariff measures on fruits and vegetable in the EU - pesticides standards and the EU entry price system. In this study, we focus on 3 selected products at a HS6 disaggregated level, namely tomatoes, oranges, and lime and lemon. The choice of these fresh and vegetable products is due to the fact that they have the potential to retain high levels of different pesticide. In addition, they represent important products subjected to the EU entry price control.

\subsection{Pesticide Standards Regulations in the EU}

Pesticides are active substance used in protecting crops from pests and diseases before and after harvest. While their major aim is to increase the quantity and quality of the produce, however, mis/use can poses significant risks to human health and the environment. This necessitates countries to place stringent safety standards on pesticide use and residue levels. Thus, stringent risk assessments are usually undertaken to determine the maximum acceptable daily intake of pesticide over a person's lifetime that would pose no adverse consequent. 
In the EU, pesticides regulation is governed by European Commission (EC) Directive $396 / 2005^{2}$, which establishes the MRLs of pesticides allowed in products of plants and animal origin intended for consumption, based on scientific evidence from risk assessments. This directive which became operational starting from September, 2008 harmonized all pesticides standards among EU Member countries With this directive, EU pesticides regulation became more encompassing as more than thrice the previous number of pesticides were regulated. Figure 1 displays the number of pesticides regulated for each of the 3 products considered in this study. The EU regulates a large number of pesticides standards on tomatoes, oranges, and lime and lemon, amounting to 468 standards in 2008 which declined to about 462 in 2013. This recent reduction in the number regulated is due to some previously regulated pesticides standards being exempted from regulation, because subsequent scientific risk assessment proves them to be safe for consumption.

\section{$<$ Figure 1 about here $>$}

While number tells us the extent of the standard, it does not however provide information about the intensity or stringency of the standard. This is provided by the maximum residue limit imposed on the pesticides. MRL is the unit of measure of pesticide standards and its stringency level. Thus such pesticide standards are regulated using the maximum residue levels of the pesticide substance found in or on food, based on good agricultural practices (GAP). The stringency level of pesticide standards is measured in part per million (given in $\mathrm{mg} / \mathrm{kg}$ ). Figure 2 displays the average stringency level of the subsets of harmonised pesticides regulated by the EU between 2008 and 2013.

\section{$<$ Figure 2 about here $>$}

The stringency of the pesticides standards in the EU differ significantly among the 3 products considered (Figure 2). From a high stringency level in 2008, pesticide standards on these 3 products became more restrictive in 2009 (a decrease in the maximum allowed is observed in Figure 2, which signifies higher stringency and thus, a more restrictive standard). Furthermore, the stringency level of oranges, and lime and lemon are more restrictive in 2011 compared to 2010, while that of tomato is more restrictive in 2013 compare to what was obtained in 2012. Thus, the net effect of this restrictiveness is an empirical one.

\subsection{EU Entry Price System for Fruits and Vegetables}

The second aspect of food regulation market germane to countries importing certain fresh fruits to the EU is a non-tariff measure in the form of 'behind the border' price requirement known as

\footnotetext{
${ }^{2}$ Prior to this, pesticide regulation used to be fragmented among the EU countries. However, its introduction repealed the four previously existing fragmented or unharmonised regulations (directives 76/895/EEC, 86/362/EEC, 86/363/EEC and 90/642/EEC) on pesticides. The directive has been consequently amended several times as new scientific evidence on previously non-established substances were discovered and old ones are amended or repealed.
} 
the EU entry price control. This system of regulation protects EU growers of 15 fruits and vegetable products including tomato, oranges and lime, from international competition by regulating the entry prices of these products from exporting countries. This is done by penalizing third countries exports whose prices fall below a predetermined seasonally varying stipulated minimum entry price, through the imposition of specific duties on these exports (Goetz and Grethe, 2010). This system of protection is known as the EU entry price system (thereafter EPS). The EPS is a non-tariff measure which aims to restrict import prices below the stipulated entry price and act to erode the competitiveness of exporters and increase the competitiveness of EU growers relative to exporters'. For instance, if the exporter supplies the product at a price below the maximum stipulated entry price as a result of having a competitive edge due to lower costs of production, then a predetermined specific duty is levied as a penalty factor. The EU EPS come into force in July 1, 1995, replacing the old reference price system.

To calculate the entry price duties, information is needed on the import price of the product and the predetermined entry price. However, in the EU a large proportion of EU fruits and vegetable imports are paid on commission, implying that the import price of the product is not determined until it is sold in the EU markets (Goetz and Grethe, 2010). The European Commission (EC) therefore calculates a 'synthetic' import price which the Commission refers to as the standard import values (SIVs). The applicable SIVs, published on a daily basis by the EC are calculated from a survey of fruits and vegetable prices for each product and export origin, collated from designated representative fruits and vegetables wholesales markets in all the EU member countries (Goetz and Grethe, 2008). For each country and product, a SIV ${ }^{3}$ is then calculated on a daily basis as a weighted average of all the wholesale market prices collated from all these representative markets, less the marketing costs, transportation costs and custom duties (EC Regulation 3223/94).

The EU schedule of entry price (EP) varies by season with lower entry prices imposed during EU off season period of the applicable fruits and vegetables, and high entry prices are imposed when the fruits and vegetables are in seasons in the EU (Cioffi and dell' Aquila, 2004). Although almost all African countries enjoy preferential access to the EU market under the 'Every Thing but Arms Agreement", in terms of zero tariff on their exports, however, this benefit does not extend largely to EP as only Morocco enjoy preferential EP duties while the others have to comply with EU's most favoured nation (MFN) market access conditions of the EPS.

\footnotetext{
${ }^{3}$ EU allows exporters 3 options in determining the applicable EPS duties applicable: standard import values, using the FOB prices and the deductive price. An option is declaring export value using FOB price which is then then adjusted for insurance and freight costs, giving rise to the CIF price. The deductive price option is based on the final selling price of the consignment as indicated by an invoice. Thus, when the SIV is far above the floor EP, this result in the very high duties, and importer may resort to using these two methods, however, the duties still applies.
} 
Table 1 shows the schedule of minimum entry prices for the 3 products considered in this study. For tomatoes and lemon, the entry price runs throughout the whole year from the first of January of the year to the thirty-first of December, as EU growers are not that competitive in producing this product. However, the entry price system runs between December and May for oranges, which correspond to the after harvest period of EU growers - a period in which oranges are out of season and EU domestic prices are less competitive. This is in sharp contrast to Africa countries most of who have relative price competitiveness all year round due to the favourable tropical region and cheaper labour. In the case of tomatoes, the EP varies between $52.60 € / 100 \mathrm{~kg}$ and $112.60 € / 100 \mathrm{~kg}$ ); for oranges, the maximum EP is $35.40 € / 100 \mathrm{~kg}$ and the minimum is $32.60 € / 100 \mathrm{~kg}$; but varies between $46.20 € / 100 \mathrm{~kg}$ and $55.80 € / 100 \mathrm{~kg}$ in the case of lemon. Exporters whose export price falls below the maximum entry price are penalised for bringing in products relatively cheaper than the domestic ones through the imposition of EP duties. For tomatoes, the duty ranges from a minimum of $0 € / 100 \mathrm{~kg}$ to maximum of 29.8 $€ / 100 \mathrm{~kg}$, the range for oranges are between $0 € / 100 \mathrm{~kg}$ and $7.10 / € / 100 \mathrm{~kg}$, and between 0 $€ / 100 \mathrm{~kg}$ and $25.6 € / 100 \mathrm{~kg}$ for lemons.

\section{<Table 1>}

The applicable EP duties are determined as follows: if the synthetic import price (in this case SIV) is equal or greater than the maximum EP in any given season, no EP duty is levied. In other words, export products whose price is equal or greater than the maximum entry price always attract zero EP duties. However, if the 'synthetic import price' is below the maximum $\mathrm{EP}$, but above the minimum EP, an ad valorem tariff plus a specific EP duty is levied on the product. If the synthetic import price is equal or below the minimum EP in any given season, the highest EP duty applies which in our case is $29.80 € / 100 \mathrm{~kg}$ for tomatoes, $7.10 € / 100 \mathrm{~kg}$ and $25.60 € / 100 \mathrm{~kg}$ for oranges and lemon respectively. Thus, the EPS penalises exporters that bring into the EU competitive exports by making cheaper exports to become more expensive.

To get a clear idea of the EPS, we take an example from the EC TARRIC website. Table 2 depicts the schedule of MFN EP levied on an African country that has a preferential agreement with the EU. On $1^{\text {st }}$ of April, 2013, the synthetic import price of tomatoes from Morocco, Tunisia and all other African countries were $75.70 € / 100 \mathrm{~kg}, 97.00 € / 100 \mathrm{~kg}$ and $98.90 € / 100 \mathrm{~kg}$ respectively (EC, 2013). Using Table 2, this implies that all these African countries bring very competitive export to the EU, and these prices are well below the EU minimum entry price of $103.60 € / 100 \mathrm{~kg}$ (case 5). Thus, protecting EU growers from this price competition led to the imposition of a penalty factor on their exports in form of an additional maximum EP duty of $29.80 € / 100 \mathrm{~kg}$, amounting to a total import price of $105.50 € / 100 \mathrm{~kg}$ for Morocco, $126.80 € / 100 \mathrm{~kg}$ for Tunisia and $128.7 € / 100 \mathrm{~kg}$ for all other African countries. The addition of this additional duty eroded the competitiveness of these exporters by making their cheap exports to become very expensive. Hypothetically, if an Africa country say Ghana was to arrive at the EU border at a CIF price of $112.6 € / 100 \mathrm{~kg}$ (case 1), no specific duty is levied on the product because the EU EPS requirement is perfectly satisfied. In this case, the CIF price is equivalent to the prevailing maximum EP of $112.6 € / 100 \mathrm{~kg}$. Thus, to avoid these EP duties, this 
might alter the exporters' pricing behaviour by making them to supply their product to the EU at the maximum possible price, so as to avoid the additional EP duties (Goetz and Grethe, 2009).

\section{<Table 2>}

\section{Africa's Export Performance}

Africa has comparative advantage in the production of agricultural products, particularly tropical food products due to its favourable climatic conditions. Part of this huge production could result in exports, serving as export earnings thereby increasing economic growth. Thus, a competitive export performance is needed to realise this goal. Table 3 shows the direction of trade of the 3 products considered in this study between 1995 and 2013. We group these years into the period of pre-harmonisation of pesticide standards in the EU (1995 to 2007) where member states were not strictly obliged to adhere to EU standards, but are given the autonomy to impose their own country specific standards on export. The other period which falls between 2008 and 2013 represent the harmonisation period when EU standards are fully harmonised among Members (Directive 396/2005).

\section{$<$ Table 3 here $>$}

In terms of direction of trade, aside intra-Africa trade, the EU represents the most important trading partners of African countries. Therefore, trade policies implemented by the EU would have implications on their export performance and would also influence their decisions on whether or not to enter into trade relations with the EU. In the case of tomatoes, most of its export has been traded within Africa, amounting to as high as $86.5 \%$ between 1995 and 2013 . $74.4 \%$ of this constituted intra-Africa trade during the pre-harmonisation period, and this increased significantly to about $91.6 \%$ following the harmonisation of standards in the EU. This represents a sign of lack of significant market access to African countries. A further look at Table 3 signifies that EU remains the major destination of tomato export, aside Africa, absorbing about $9.4 \%$ of the continent tomato export between 1995 and 2007. This share however fell drastically to about $2.9 \%$ in the harmonisation period in the EU, not only due to the increased number of pesticides now regulated in this period but also due to the very stringent standards set by the EU to guide against risk from pesticide overdose. The fall in African export of this product could be attributed to the high cost of upgrading their supply facilities in order to comply with the new set of EU standards which is aggravated by the continent's lack of adequate financial and technological resources to successfully comply with such stringent standards (Otsuki et al, 2001).

Apart from this, the EU entry price control on this product might be inhibiting their ability to access EU markets. In other words, EU price control which penalizes competitive exporters through the imposition of additional duties on African exporters who brings in competitive exports to the EU might also explains the declining exports to EU markets. In fact Chemnitz and Grethe (2005) found the EU entry price system to inhibit Morocco's tomato exports to the 
EU, and we proffer that similar effect might hold for these other African countries. It is important to note that the precedent fall in Africa's tomato exports to the EU in this period has led to trade diversion to other countries that have less stringent standards and no entry price control, particularly to Jordan and some other African countries that absorbed the excess supply of the product.

However, the case of Africa's export of orange is somewhat different. Intra Africa trade still constitute the main avenue where these exports are absorbed, which is about $80 \%$ in both pre and post harmonisation period. The high percentage of intra-Africa trade might indicate the lack of adequate market access to other markets. Remarkably, African export of oranges to the EU accelerated from about $13 \%$ in the pre-harmonisation period (1995 to 2007) to about 18.9 in the post harmonisation period despite the prevalence of more stringent standards and increased in the number of regulated standards in this period. This might be indicative of the fact that these exporters were able to comply with the safety standards, which accelerated their increased penetration of EU markets. In addition, this improved market access to EU markets might also indicates that complying with EU entry price requirements does not constitute a huge barrier to export penetrations, at least for those who are exporting.

Similar results was found for lime and lemon as the EU still remains the most important trading partner of this product, apart from intra trade within Africa which constitute about $68.1 \%$ and $66.7 \%$ in the pre and post harmonisation period respectively. Africa's direction of trade to the EU improved from 18.9\% between 1995 and 2007 to $27.4 \%$ between 2008 and 2013 following the harmonisation of EU standards. In fact, African satisfied this increased export supply to the EU by diversifying a significant percentage of its export from Argentina in order to meet the increased import demand in the EU. This increment was realized in spite of the fact that the period coincide with period in which EU enacted more stringent food safety pesticide standards. The increased export penetration might also signal that the EU entry price control does not translate into a surmountable barrier for these African countries, although the exact impact remains an empirical one.

Thus, the direction of trade indicates that the EU remains the largest most important international trading partner of African export for the 3 selected products and that African's tomato exports witnessed significant decline during the EU period of standards harmonisation while her export of oranges, and lime and lemon accelerated in the same period.

\section{Empirical Analysis}

To investigate the trade impact of the two EU food regulations, we employ the gravity model which predicts that bilateral export between two countries is explained by economic masses between the trading countries and the geographical distance between them (Tinbergen, 1962; Pöyhönen 1963). Gravity model has been widely used to estimate the effects of trade policies, migration; currency union, regional trade agreements (Anderson and van Wincoop, 2003; Baier and Bergstrand, 2010). Its general acceptance as the workhorse of international trade and its proven popularity are primarily due to its exceptional success in predicting bilateral trade flows and the theoretical foundations given to it by trade theories. 


\subsection{Methodological Framework and Model Specification}

The theoretical model for our analysis is based on firm heterogeneity behavior which shows that due to the heterogeneous behaviour of firms, a small fraction of firms finds it profitable to export and while others choose not to as they are less productive. Thus, this makes the trade matrix to contain both positive and zero trade flows. The intuition is that EU market conditions on food might affect the probability of African countries exporting to the EU, with productive firms exporting and non-productive firms choosing not to export.

Our empirical strategy is therefore to measure the effect of EU food regulations on Africa's on the probability to export. Our model is similar to Nicita and Roll (2015) which analysed the impact of tariff on the extensive margin of trade for sub-Saharan exports. Similarly, we employ a probabilistic model to explore the implication of EU entry price system and food safety standards on the probability of exporting. More so, our bilateral exports data contain many zeros, thus allowing us to exploit the presence of zero trade flows along the extensive margin. More explicitly, the dataset on exports of tomatoes, oranges, and lime and lemon contains respectively about $86 \%, 79 \%$ and $82 \%$ zero trade observations between the trading countries. Although such zero flows can be attributed to statistical zeros such as rounding up, however, many of these zeros are likely to reflect Africa's inability to trade as a result of the market access conditions set by the EU. Given this, our model is specified as:

$\rho_{i j t}=P\left(T_{i j t}=1 \mid x_{i j t}\right)=\Phi\left(\beta_{0}+\beta_{1} \ln Y_{i t}+\beta_{2} \ln Y_{j t}+\beta_{3} \ln F R_{i j t}+\beta_{4}\right.$ Initial__Status $_{i j t}+$ $\beta_{5} \ln$ dist $_{i j}+\beta_{6}$ Lang $_{i j}+\beta_{7}$ Col $\left._{i j}+\beta_{8} R T A_{i j t}+\varepsilon_{i j t}\right)$

Equation 1 is a probit model which determines the binary decision of whether to trade or not. The subscripts $i, j, t$ and $\ln$ denote exporter, importer and time and logarithm respectively. The dependent variable $\rho_{i j}$ is the probability that country $i$ exports to country $j$, conditional on the observed variables; $T_{i j t}$ is a binary variable which is equal to 1 if country $i$ exports to country $j\left(T_{i j t}=1\right)$ and zero when it $\operatorname{does} \operatorname{not}\left(T_{i j t}=0\right)$, where $Y_{i t}$ and $Y_{j t}$ are respectively the exporting and importing countries nominal GDP measured in US dollars. $F R_{i j t}$ is the EU food regulations which spans entry price conditions and food safety standards. Dist ${ }_{i j}$ is the geographical distance between countries $i$ and $j$. Lang, Col, and RTA are dummy variables which take the value of one when both the exporting and importing countries share a common language and have colonial ties, belong to the similar trade agreement, respectively, zero otherwise; and $\varepsilon_{i j t}$ is the idiosyncratic error term which is assumed to be well-behaved. These two measures of EU food regulations enter separately into equation (1) in order to disentangle their relative importance on Africa's exports potential. The construction of these two measures is discussed in detailed in a later section.

To obtain consistent estimates, we control for multilateral trade resistance terms using Baier and Bergstrand (2010) first order Taylor series approximation of bilateral trade costs using simple averages. Their approach also produces similar estimates similar to Anderson and van Wincoop (2003) structurally iterated least square method. For each trade cost variable, the first order Taylor series is expanded and all the newly demeaned bilateral trade cost variables are transformed using the following approximation: 


$$
\left(x_{i j t}\right)_{P_{i} P_{j}}=x_{i j t}-\frac{1}{N} \sum_{j=1}^{N} x_{i j t}-\frac{1}{2} \frac{1}{N^{2}} \sum_{i=1}^{N} \sum_{j=1}^{N} x_{i j t}
$$

where $x$ stands for any of the variables associated with coefficients $\alpha_{3}$ to $\alpha_{7}$ in equation $1 ; P_{i} P_{j}$ is multilateral trade resistance terms ${ }^{4}$. The first term on the right hand side $-x_{i j t}$ is the contribution of $x$ to $P_{i} P_{j}$, and $N$ is the number of bilateral observations on exports. The second term on the right hand side is the simple average of gross trade costs facing exporter $i$ across all importer $j$. The third term on the right hand side denotes the simple average of all trade costs faced by importer $j$ across all exporters.

\subsection{Measuring EU Food Regulations}

This section provides information on how the two measures of EU food regulations on entry price and food safety standards were constructed.

\subsubsection{Measure of EU Entry Price System}

We constructed two distinct indicators at the bilateral level to capture the impact of EPS on Africa's export. The first indicator that we constructed was the corresponding duties imposed by the EU due to the price control. The Second indicator measures the difference between the import price of the product and the corresponding EP. We used the SIVs as a measure for the EU import price of the commodity which is the imported price of the commodity less the marketing and transportation costs and custom duties.

The first indicator is the calculation of the EP duties arising from the enforcement of the EPS by the EU on the 3 Africa's exported products considered in this study. For each product, the effectively applied daily EP duties measured in EUR per $100 \mathrm{~kg}$ were manually computed. This sums up to about 365 data points in a year, resulting into a total of 2192 data points per product, between 2008 and 2013. The daily ad valorem tariff an equivalent of these duties was thereafter calculated using the 'WTO agricultural method'. From this, a simple yearly average of the daily ad valorem tariff is calculated and used in our analysis. A priori, we expect that the EP tariff will have a negative impact on export flows.

However, based on anecdotal evidence and producer pricing behaviour, the rational exporter may supply her export products at the maximum possible price to the EU when complying with the EP, so as to avoid the EP duties (Groetz and Grethe, 2009). This is because no entry price duty is incurred on exports supplied at prices corresponding to, or slightly higher than the maximum EP. In this case all or most of the observations of our first indicator would be zero. Indeed, such pricing behaviour might make the exporter to supply the product at a price greater than what is obtainable in the domestic markets in the EU, which consequently erode the exporters' competitive cost advantage. Thus, we introduce another variable to capture this

\footnotetext{
${ }^{4}$ According to Anderson and van Wincoop (2013), countries not only face bilateral trade costs when trading, they also face multilateral trade costs which is defined as all trade costs facing a given country from all trading partners. Omitting the multilateral trade costs will give bias gravity estimates and is popularly known as the 'gold medal error' (Baldwin and Tagloni, 2006)
} 
pricing behaviour. The second indicator which we termed Gap captures the difference between the import price of the product (measures by the product's SIV) and the corresponding maximum EP (which attracts always zero entry duty). This indicator is then given as:

$$
G a p_{i j t}=S I V_{i t j}-E P_{i t j}^{m}
$$

Where $i, j$, and $t$ are respectively exporter, importer and time subscripts. $S I V$ is the synthetic import price measured in dollar per $100 / \mathrm{kg}$ and $E P^{\mathrm{m}}$ is the yearly maximum entry price measured in dollar per $100 / \mathrm{kg}$. This indicator is somewhat similar to that used by Goetz and Grethe (2009) with the exception that theirs is a relative indicator as the right hand side of equation (8) is divided by the EP, while ours is an absolute one. Using equation (3), observations on GAP can exhibit two distinct trends: it can either be less than zero, or greater or equal to zero. First, we deduce that if $G A P_{i j t}<0$, the import price is below the maximum EP; and thus an increase of the import price above the entry price brings about the imposition of entry duties which erode the price competitiveness of the export goods. Thus, observations in which $G A P_{i j t}<0$, export competition is eroded. Second, for observations with $G A P_{i j t} \geq 0$, then, the import price is equal or greater than the maximum EP, and no entry duty is levied.

Cases of the import price being above the EP leads to a decrease in export price competitiveness, as the final price of the exports becomes more expensive relative to similar domestic goods, discouraging export purchases and thus inhibiting exports supply to the EU. However, cases in which the SIV is below the maximum EP means that EP duties would be incurred, thus making the final price of the exports to become more expensive. Adding in the EP duties to the synthetic import price (SIV) increases the final export price above the prevailing domestic price, thereby also discouraging exports. So, either way, the coefficient will be negative. This will hold unless the entry price duties is such that when added to the SIV, the final price of the exported good is so small that it falls below the prevailing domestic prices, such that export is still relatively cheaper than domestic goods. Or if the prevailing synthetic import price plus the duties is such that it is still lower than the domestic price for the good (such that the home market is a dumping ground for the product). If these last two scenarios are the case, then, the coefficient of this variable will be positive a priori. Given this, the coefficient of this indicator can be negative, positive or even insignificant and the exact impact is an empirical question.

\subsubsection{Stringency of Standards}

We constructed a simple pesticide standard restrictiveness index by combining information on the total number of pesticides regulated and level of stringency of the pesticides. On average, stringency of the standards is expected to increase as more pesticides are regulated, and the higher the level of pesticides standards, the lower its stringency level. The standard restrictiveness index is then:

$$
S R I_{i j p t}=\frac{1}{n} \sum_{k=1}^{n} M R L_{i j k t}
$$


Here, $n$ is the no of regulated pesticides in the importing country. The MRL of pesticides is measured in parts per million and expressed as $\mathrm{mg} / \mathrm{kg}$, and SRI is the pesticide standard restrictiveness index which measures the yearly average MRLs of all pesticide $p$ imposed by importer $j$ on $i$ 's exports over time $t$. Lower MRL signifies higher stringency of the pesticide standards and vice versa, thus, the lower the index is, the higher the stringency of the pesticide standards. The regulated pesticide restrictive index can then either have a direct or an inverse relationship with exports. A positive coefficient on it implies that standard is trade inhibiting as standards have a direct relationship with exports such that a decrease in the value of the standard restrictiveness index (increase in stringency) decreases exports. However, a negative value denotes that standard is trade promoting as standard has an inverse relationship with exports - such that a decrease in the stringency (increase in standard) increases exports. Given this, the coefficient on the index is expected to be positive if the pesticide standard limits trade.

\subsection{Data Sources}

Our dataset covers bilateral exports from selected African countries to the European Union countries who are major trading partners between 2008 and $2013^{5}$. A list of countries included in the analysis is available in the appendix. Bilateral exports data was extracted from UN COMTRAD Via World Integrated Trade Solution (WITs) database at the Harmonised System digit 6 level. This covers 3 unique dataset on African exports of tomatoes (070200), oranges (080510) and, lime and lemon (080550) to the EU. Data on distance, language and colony were collected from the Centre d'Etudes Prospectives et d'Informations Internationales (CEPII) database; GDP data was from the World Bank World Development Indicator, while data used in constructing the regional agreement dummy was from the World Trade Organisation. Data on pesticide standards was manually collated online from the EUROPA database which houses a rich database of all pesticide standards developed and adopted by all EU Member States between 2008 and 2013. Data on EU entry price measures and duties in Euro was manually collated from EC TARIC website and was converted to US dollar using exchange rate data from the World Development Indicators dataset, 2014. The ad-valorem equivalents of the entry price duties were calculated using the WTO Agricultural method based on trade data from UN COMTRADE. Daily data on country specific standard import values on each product set by the European Commission are obtained from European Union designated daily publications.

\subsection{Results and Discussion}

The result of our probit equation estimated separately for the 3 unique datasets on tomato, lime and lemon, and orange are presented in this section. All models are estimated using randomeffects probit model with robust standard errors clustered across panels (exporter-importeryear). The reported estimates are the marginal effects of the probit model.

\subsection{Impacts of EU Food Safety Standards on Africa's Exports}

Table 4 presents the results of the estimation of EU pesticide standards on African exports of the 3 selected products. The main results indicate that standards imposed by the EU on these products are barrier to Africa's exports penetration. For all 3 products, regulated EU pesticide standards turn out to be positive and significant, implying that standards have a direct

\footnotetext{
${ }^{5}$ The choice of our period of analysis hinges on two factors. First, access and availability of EU pesticide data starts from 2008. Second, this period is an important period in which pesticide standards were harmonised in EU (EC 396/2005) and the application of pesticides standards are more transparent.
} 
relationship with exports such that a decrease in the standard (increase in the stringency of the pesticides standards) decreases the probability of exporting all 3 products to the EU. The average marginal effect on the probability of exporting is $6 \%$ for tomatoes, $7 \%$ for lime and lemon, and $4 \%$ for oranges and these are all on the prohibitive side. Our result confirms those of Wilson and Otsuki (2004), Chen et al. (2008) and Winchester et al. (2012), all authors find that pesticide standards can inhibit export penetration, and more recently by Xiong and Beghin (2014) and Ferro et al. (2015) who find pesticide standards hinder the likelihood of trade mainly through the extensive margin, particularly for developing countries.

\section{<Table 4 here>}

This result is as expected since as high as $70 \%$ of Africa's fruits and vegetables products were rejected by the EU between 2008 and 2013 for exceeding EU pesticide residue limits (EC RAFFS, 2014). Furthermore, these products are part of the list of pesticide-contaminated fruits and vegetables that retain the high levels of pesticides residues and are more likely to test positive for multiple pesticides (EWG, 2013). Thus, this product attracts the most stringent standards to protect consumers, implying additional fixed costs to comply with them, which might be too much to bear for the small scale producers, most of which constitute exporters of this product in Africa. In addition, the EU has been extending technical assistance to some farmers, producers and exporters in Africa, Caribbean and Pacific (ACP) countries to enable them satisfy its safety standards and access EU markets. Two of such development cooperation are the Europe-Africa-Caribbean-Pacific Liaison Committee and Pesticide Initiative $\mathrm{P}$ Programme (PIP) both of which have been supporting ACP fruits and vegetable sectors in order to maintain or increase the contribution of horticultural export on poverty reduction. However, potential exporters have not been able to benefit from such assistance and this could possibly explain their low potential to export to the EU and why standard constitutes a significant market access problem for them. The problem of complying with EU stringent pesticide standards is further aggravated for these African countries due to their lack of technical and financial capacity to satisfy EU standards and the lack of scientific knowledge to do so. This has led to significant trade diversion to other countries. For example, prior to the harmonisation of EU pesticide standards in 2008, African exported about $9 \%$ of its tomatoes to the EU. However with the new EU harmonisation law, the associated increase in the stringency of standards forced African's exports to the EU to fall to $2.9 \%$ with Africa redirecting its exports to the countries in the Middle East, particularly Jordan (Kareem, et al. 2015).

On the supply side, the economic masses of African countries proxied by their GDPs do not significantly encourage the exportation of these products except for lime and lemon. This is in spite of the fact that Africa produces about 7 to 13 per cent of total world export of tomatoes and oranges in the last few years (FAOSTAT, 2014). Similar results were obtained by Mayer and Fajarnes (2008); Beghin and Xiong (2012) and Kareem et al. (2015) who confirmed that domestic market constraint such as countries' sizes constitute a major constraint to Africa's export penetration. Our results indicate that the exporting African countries income allocated to agriculture has not been significant in luring new exporters into this trade, thereby constitution an important constraint to initiating new trade relationships and might explain why some African exporters are gradually disappearing such that some export in some years and not in others (zero trade flows). An exception are lime and lemon exports where we see that Africa countries' income or productive capacity has been able to enhance the probability of exporting 
these products to the EU, such that a one percent increase in the income base of Africa has increased the probability of exporting to the EU by $0.25 \%$. However, this productive capability is still low relative to the income growth the continent is experiencing in recent years.

In contrast, on the demand side, the absorptive capacity of EU consumers measured by EU countries' GDP is able to stimulate new trade, for all 3 products. However, the value is relatively low for tomatoes. One plausible reason for this is the unwillingness of EU consumers to consume conventional tomatoes and their increased preference for organic products. Nevertheless, this positive absorptive capacity of the importing countries in contrast with the weak productive capacity of the exporting countries indicates that a continuous promotion and expansion of this commodity is needed in order to meet the relative high import demand and harness immense benefits from trade.

Regarding the other control variables, most of them are significant with the expected signs. Africa's probability of exporting to the EU depends largely on whether the product was already exported in the initial period (initial_status). In other words, products already exported in year 2008 (which is the start of the harmonisation of EU food regulations) have a high probability of being exported in subsequent years. In relation to other trade costs, distance hinders the exports of the three products to the EU. In particular, we find that the distant effect is largest for tomatoes exports representing about 3.9\% decrease in probability of exporting as a result of a one percent increase in kilometre. This indicates the reluctancy to export tomatoes as a highly perishable product over such a long distance due to the transportations risk associated with it. Major reasons adduced for this large distance effect are the high cost incurred by the continent when conducting international transactions (Djankov et al., 2010), and Africa's weak trade facilitation infrastructures which results into higher trade cost for the continent (Iwanow and Kirkpatric, 2009; Portugal-Perez and Wilson, 2012). In addition, the probability of exporting these products turn out to depend largely on sharing common language and colonial ties with the EU. However, common language between the two trading partners has no apparent impact on the decision to export lime and lemon to the EU, while in the case of tomatoes, colonial tie between the country-pairs actually reduces the probability of trading.

In addition, having a trade agreement relationship with the EU is a stimulating factor for potential African exporters in establishing possible new trade relationship, significantly impacting on Africa's probability of exporting oranges to the EU. It has however no apparent effect on tomato as well as lime and lemon exports to the EU, which means that RTAs should be negotiated product by product and not at the aggregated level. However, one possible explanation for this is that regional trade agreements with the EU would not increase trade unless these exporting countries comply with EU pesticides standards which is applied on an MFN basis. Aside this, the benefits from all the RTAs between Africa and the EU have been in form of preferential tariff to selected African countries while non-tariff measures are applied on an $\mathrm{MFN}^{6}$ basis with no preferential treatment even for countries in RTA relationships with the EU. This could thus explain why standard as a non-tariff measure constitute a significant market access problem for Africa. Aside this, other reasons adduced for this result are the lack of potential to harness the benefit for their use due the numerous Africa's domestic market

\footnotetext{
${ }^{6}$ Unlike tariff, most non-tariff measures such as food safety standards are regulated to achieve non-trade objectives and thus, could not be negotiated away the way tariff can. Thus, it is usually applied on an MFN basis.
} 
constraints in terms of high level of corruption in the continent, inadequate education, their lack of sophisticated science and technology to improve their export products to the EU. Other factors are the hidden constraints or conditions in the RTAs such as rules of origin, EU minimum entry price control, all of which hinders Africa's ability to penetrate the EU market. This implies that deeper agreements are needed to integrate African countries and to ensure their market access to the EU.

\subsection{Impacts of EU Entry Price Conditions on Africa's Exports}

We now turn to investigate the effect of the second market access variable on the potential of generating export relationship with the EU. In relation to our market access variables, the estimates reported in Table 5 indicate that the EU entry price duty does not significantly affect the probability of exporting except for the case of tomatoes. In other words, the entry price system of the EU which penalize exporters whose standard import price is below a specified minimum entry price, is a significantly hurdle for tomato exporters to penetrate EU markets. More specifically, the coefficient on the ad-valorem entry price duties tomatoes exporters incurred from supplying their products below EU entry price is significant and negative, implying that entry price duties represent an important market access barrier for these potential tomatoes exporters. In essence, supplying tomatoes to the EU below the predetermined entry price by one percent brings about the imposition of duties which significantly decrease the probability to trade with the EU by as high as $14 \%$. This is expected since entry price duties would be incurred as a penalty factor when the import price is below the maximum entry price, thus making cheaper exports more expensive and less competitive in EU markets. Consequently, the additional entry price duties increases the final import price above the prevailing domestic price in the EU, thereby discouraging exports and might force exporters to look for other markets and abandon the EU market, as EU entry price system inhibits trade much more than the regulated EU pesticide standards.

\section{$<$ Table 5 here $>$}

On a related note, the second indicator of EU EPS (entry price GAP) which measures the competitiveness of Africa's tomatoes import price of tomatoes supplied by Africa relative to domestic growers' is also statistically significant and negative, showing that the imposition of the entry price erodes Africa's price competitiveness. In fact, a one dollar increase in Africa's price of importing tomatoes above the EU ceiling entry price reduces exports by $9.3 \%$ \{ that is $\left.e^{0.089}-1 * 100\right\}$. The increase of the import price of tomatoes above the entry price brings about the imposition of additional duties which erodes the price competitiveness of tomato export. This leads to a decrease in export volume, as the final price of the exported good becomes more expensive relative to EU domestic prices, discouraging export purchases and creating market access problem for potential tomato exporters. Similar results were found by Chemnitz and Grethe (2005) on Morocco tomato exports to the EU and by Goetz and Grethe (2010) on China's exports of apples and pears to the EU.

However, in the case of lime and lemon as well as oranges, the trade impacts of the two variables capturing the EU entry price system are statistically indistinguishable from zero. This indicates that EU entry price system shows no apparent effects on these products and thus is not be relevant for these exporters in establishing new trade relationship with the EU or extending their products to new markets in the EU. More specifically, the first variable which is the EPS 
duty is insignificant and thus irrelevant to export penetration Africa's export market access to the EU. One plausible explanation for this might be that most of these exporters are already producing at a competitive price at home, as they have relative comparative advantage in the production of these commodities due to a tropical climate which favours their production all year round. Thus, most of the countries produce at relatively lower costs compared to the EU growers such that no amount of extra duties incurred could discourage them from exporting to the EU. Consequently, the imposition of EU entry price duties on these products does not erode their price competitiveness; the import price is already highly competitive such that no stipulated amount of additional ad valorem tariff can erode such competitiveness. In fact, the entry price is of no relevance to them in their decision to export or not to export to the EU.

Complementarily, the second variable (entry price GAP) is also not a significant market access problem for trade in lime and lemon as well as oranges. One possible explanation of this result is that plausibly, the exporters already have competitive cost advantage over EU growers and thus are supplying oranges at the lowest possible price while complying with the EP such that they are able to avoid paying the EP duties. Thus, this result implies that for lime and lemon as well as oranges exports, EU entry price system is not relevant in the decision to enter new trade relationship with the EU, while EU stringent pesticide standards is a more problematic factor in penetrating EU markets. Similar results was reported by Goetz and Grethe (2007) who found EU entry price control is of low importance for exports of oranges from selected Mediterranean countries to the EU. Our result also confirms those of Cioffi and dell' Aquila (2004) regarding southern exporters to the EU.

Turning to the control variables, the estimates in Table 5 show that importers' GDP, and initial status are the major factors driving the African exporters' possibility of establishing new trade relationships with the EU. In fact, the findings in Table 5 are closely similar to those obtained in Table 4, and therefore a similar interpretation applies.

\section{Robustness Checks}

We did a number of checks to assure the reliability of our results. Our first paramount concern is whether our results are driven by economically small export flows. We therefore excluded countries $^{7}$ with value of less than a thousand USD bilateral exports to the EU to check if these outliers are the one driving the results obtained. The results of this check are presented in Table 6. These results further highlight our previous conclusion since they are similar to those obtained in Tables 4 and 5, although the coefficients of the target variables are slightly lower in magnitude. Nevertheless, the basic message of this study in relation to the impact of the two non-tariff measures remains largely unchanged.

\section{<Table 6 here>}

\footnotetext{
${ }^{7}$ The excluded countries are in the tomato dataset, Chad, Libya, Mauritius, Sam Tome and Zambia; Drop Mozambique, Niger, Cameroon, Togo, Guinea Bissau for the lime and lemon dataset and Chad, Guinea Bissau, Sao Tome, Sierra Leone, Gambia are excluded in the orange dataset.
} 
A second concern is whether the results are driven by the characteristics ${ }^{8}$ of the exporting countries such as 'outlier countries' with huge GDP. To address this concern, we have excluded Nigeria and South Africa from our datasets as they are the two most important countries with huge economic growth in Africa. The results presented in Table 7 are similar to those obtained in Tables 4 and 5 and so, our major conclusion remain the same, meaning that our results are robust to the exclusion of the two largest African countries.

\section{$<$ Table 7 here >}

Lastly, there are concerns that standards could be endogenous and might have appeared following an import surge (Essaji, 2008; Ferro et al., 2015). Under pressure from lobby groups, the EU might have enacted regulations on MRLs of pesticides to deliberately limit import flow in a particular sector. Following these presumption, some studies have used the lagged values of standards as instruments. However, based on anecdotal evidence, we argue that EU standard is rather exogenous in nature, at least for MRL of pesticides. This is because it takes at least about 10 years to get a first approval for pesticides in the EU (Article 5, EC 1107/2009) and a minimum of 3 years to get a second stage approval for already approved pesticides. In addition, all approved pesticide substances that have been on the EU market for 10 years or more are periodically reviewed after 10 years. This scenario thus depicts that EU pesticides standards might not have appeared following an import rise and thus, it is not necessarily endogenous. However, as a robust check we used lagged values of pesticides standards as instrument. Since our analysis covers 6 years, we used the first lag of standards as instruments to avoid losing a lot of observations and degree of freedom. We presume lagged values to be appropriate instruments due to two reasons: current standards are highly correlated with previous ones, and current export flows cannot influence previously enacted standards. Columns 2 through 4 of Table 8 report the results which are consistent with our previous findings. EU standards reduce the probability of exporting as standards deters potential exporters from accessing EU markets due to the costs needed to upgrade their supply and production chains in order to comply with EU standards.

\section{<Table 8 here $>$}

\section{Conclusion and Policy Implications}

This study investigates the impact of two non-tariff aspects of EU food regulation on tomatoes, oranges, and lime and lemons exports to the EU. Our results have several implications for stimulating exports and encouraging potential exporters in Africa. Our main results show that EU standard inhibits exporters' probability to export to the EU for all 3 products. In addition, we found the EU entry price control to have no apparent effect on potential exporters of oranges and lime and lemons, but exert significant negative influence on the probability of exporting tomatoes to the EU. Our results also indicate government's neglect of promoting and

\footnotetext{
${ }^{8}$ To address this concern, Nigeria and South Africa are excluded from our exporting countries sample as they are the two most important countries in terms of having huge economic growth.
} 
expanding the production of these export products, given the low magnitude and or insignificant sign of the exporters' GDP obtained in most cases. This points out that apart from market access problem, the root of Africa's marginalization in world trade is multiple, indicating that fostering the continent's integration with the global economy will require policies targeted at removing both domestic supply constraints and ensuring external demand for the continent's exports.

This study find standards can and indeed act as an impediment to initiating export relationship with the EU. However, according to Jaffee and Henson (2004), this is not always the case as increased and tightening of standards can also serve as catalysts for poor countries to participate in international trade if such countries adhere to the standards set by importing countries. Numerous technical and financial assistances are being extended by the EU and United Nations Industrial Development Organization (UNIDO) to selected African exporters to assist them in complying with stringent standards and also prepare them for export markets. This has made exporting countries to upgrade their supply capacities to fit importing countries standards, to reposition themselves in competitive international markets and enhance market access (Jaffee and Henson, 2004). Thus, such assistance should also be extended to potential exporters and should be targeted to ensure compliance with EU standards and prepare them for exporting to the EU so as to reap maximum economic benefit.

More importantly, trade negotiations with the EU should include the provision of sophisticated technological and scientific assistance to Africa's agricultural sector, particularly to small-scale producers dominating the scene, so as to assist them in complying with EU standards and enhance continuous market access for the continent. In addition, agreements with the EU negotiated to ensure the provision of preferential entry price control for African countries to enable them maintain their competitiveness in EU markets are important policy imprints for the African policy makers. At the country level, policy should be channeled towards the removal of domestic market constraints which will increase production for export. This could be achieved through a whole hearted commitment to the implementation of strong regulatory framework and the development of strong institutions that would boost country-level capacity to satisfy food safety requirements. All these blueprints needed to be faithfully implemented for trade to serve as a promising avenue to boost economic growth for the continent.

\section{References}

Anderson, J.E. and E. Van Wincoop (2003), 'Gravity with Gravitas: A Solution to the Border Puzzle', American Economic Review, 93, 170-192.

Baller, S. (2007), 'Trade Effects of Regional Standards Liberalization: A Heterogeneous Firms Approach', World Bank Policy Research Working Paper. World Bank

Baier, S. and J. H, Bergstrand (2010), Approximating General Equilibrium Impacts Of Trade Liberalizations using the Gravity Applications to NAFTA and the European Economic Area," in Brakman, S., and P. van Bergeijk (eds.), The Gravity Model in International Trade: Advances and Applications (Cambridge, UK: Cambridge University Press).

Bao, Xiaohua and W. Chen, (2013), 'The Impacts of Technical Barriers to Trade on Different Components of International Trade,' Review of Development Economics 17, 447-60.

Blind, K. 2004, 'The Economics of Standards: Theory, Evidence, Policy (Edward Elgar Publishing). 
Chemnitz, C. and H. Grethe (2005) 'EU Trade Preferences for Moroccan Tomato Exports Who Benefits?', Contributed Paper, XI Congress of European Association of Agricultural Economists, Copenhagen. August 24-27.

Chen, C., J. Yang and C. Findlay (2008), 'Measuring the Effect of Food Safety Standards on China's Agricultural Exports', Review of World Economics/Weltwirtschaftliches Archiv 144, 1, 83-106.

Czubala, W. B. Shepherd and J.S. Wilson (2009), 'Help or Hindrance? The Impact of Harmonized Standards on African Exports', Journal of African Economies, 18, 5, 711 744.

Djankov, S., C. Freund and C. S. Pham (2010), 'Trading on Time'. The Review of Economics and Statistics, 92, 166-173.

Drogué, S. and F. Demaria (2012), 'Pesticides Residues and Trade: the Apple of Discord?', Food Policy, 37, 6, 641-649

EWG (2013), Environmental Working Group Annual Report, accessed December, 2014 from http://www.ewg.org/2013annualreport/?_ga=1.39791009.300213992.141518414

EC RASFF (2014), European Commission Rapid Alert System for Feed and Food Publications and Database, http://ec.europa.eu/food/safety/rasff/reports_publications/index_en.htm [Accessed November, 2014]

EC TARIC (2014), European Commission Integrated Tariff of the European Union database, http://ec.europa.eu/taxation_customs/dds2/taric/taric_consultation.jsp?Lang=en

[Accessed September, 2014]

European Commission, Various Issues. 'Official Journal of the European Communities on Standard Import Values', http://old.eur-lex.europa.eu/RECH_mot.do?ihmlang=en [Accessed August, 2014]

Feenstra, R.C. (2004), Advanced International Trade. Theory and Evidence. Princeton University Press, Princeton.

Ferro, F., T. Otsuki, J. S Wilson (2015), 'The Effect of Product Standards on Agricultural Exports', Food Policy, 50, 68-79.

Francois, J. and M. Manchin (2013), 'Institutions, Infrastructure, and Trade', World Development, 46, 165-175

Goetz, L. and H. Grethe (2009), 'The EU Entry Price System for Fresh Fruits and Vegetables Paper Tiger or Powerful Market Barrier?', Food Policy, 34, 81-93

Goetz, L. and H. Grethe. (2010), 'The Entry Price System for Fresh Fruit and Vegetable Exports From China To the EU - Breaking a Fly on the Wheel?' China Economic Review 21, 377-393:

Gebrehiwet, Y. S. Ngqangweni and J. F. Kirsten. (2007) 'Quantifying the Trade Effect of Sanitary and Phytosanitary Regulations of OECD Countries on South African Food Exports', Agrekon 46, 1: 23-29.

Iwanow, T. and C. Kirkpatrick (2009), 'Trade Facilitation and Manufactured Exports: Is Africa Different?', World Development, 37, 1039-1050.

Jaffee, S. and S. J. Henson (2004), 'Standards and Agro-Food Export from Developing Countries: Rebalancing the Debate. World Bank Policy Research Working Paper Series, No. 3348.

Kareem, F.O, B. Brümmer and I. Martinez-Zarzoso (2015), 'The Implication of European Union's Food Regulations on Developing Countries: Food Safety Standards, Entry Price System and Africa's Exports' GlobalFood Discussion Paper Series No. 61.

Maskus, K.E., T. Otsuki and J. S. Wilson (2001), 'An Empirical Framework for Analyzing Technical Regulations and Trade', in K.E. Maskus and J.S. Wilson (eds.), Quantifying 
the Impact of Technical Barriers to Trade: Can it be Done?, University of Michigan Press, Ann Arbor.

Mayer, J. and P. Fajarnes (2008), 'Tripling Africa's Primary Exports: What, How, Where?', The Journal of Development Studies, 44, 80-102.

Moenius, J. (2004), 'Information Versus Product Adaptation: The Role of Standards in Trade', International Business and Markets Research Center Working Paper, Kellogg School of Management Working Paper, Northwestern University, Evanston.

Nicita, A., and V. Rollo, (2015) "Market Access Conditions and Sub-Saharan Africa's Exports Diversification." World Development, 68: 254-263.

Otsuki, T., J. S. Wilson and M. Sewadeh (2001), 'What Price Precaution? European Harmonisation of Aflatoxin Regulations and African Groundnut Exports', European Review of Agriculture Economics, 28, 3, 263-284.

Portugal-Perez, A. and J. S. Wilson (2012), 'Export Performance and Trade Facilitation Reform: Hard and Soft Infrastructure', World Development, 40, 1295-1307

Pöyhönen, P. (1963) 'A Tentative Model for the Volume of Trade between Countries', WeltwirtschaftlichesArchiv, 90, 1, 93-99.

Reis, J.G. and T. Farole, 2012. Trade Competitiveness Diagnostic Toolkit. Washington, DC: World Bank. Retrieved from https://openknowledge. worldbank.org/handle/10986/2248, [Accessed September, 2014].

Reardon, T., C.B. Barrett, J.A. Berdegué, and J.F.M. Swinnen. 2009. Agrifood Industry Transformation and Small Farmers in Developing Countries. World Development 37, 11, 1717-1727.

Shephard, B. and N.L.W, Wilson (2013), 'Product Standards and Developing Country Agricultural Exports: The Case of the European Union', Food Policy, 42, 1-10.

Tinbergen, J. (1962) Shaping the World Economy: Suggestions for an International Economic Policy, New York: The Twentieth Century Fund.

UnNevehr, L.J., ed., (2003). 'Food Safety in Food Security and Food Trade', 2020 Vision Focus 10, International Food Policy Research Institute (IFPRI)

Wilson, J.S., and Otsuki, T., (2004) 'To Spray or not to Spray: Pesticides, Banana Exports, And Food Safety', Food Policy, 29, 2, 131-146

Winchester, N., Rau, M.-L., Goetz, C., Larue, B., Otsuki, T., Shutes, K., Wieck, C., Lee Burnquist, H., Pinto de Souza, M. J., Nunes de Faria, R., (2012). The Impact Of Regulatory Heterogeneity on Agri-Food Trade. World Economics, 35, 8, 973-993

World Bank (2012) 'Africa Can Help Feed Africa: Removing Barriers to Regional Trade in Food Staples', available from http://siteresources.worldbank.org/INTAFRICA/Resources/Africa-Can-Feed-AfricaReport.pdf. [Accessed September 15, 2013].

Xiong, B. and J. Beghin (2012) 'Does European Aflatoxin Regulation Hurt Groundnut Exporters from Africa?' European Review of Agricultural Economics, 39, 2012, 589609.

Xiong, B. and J. Beghin (2014) 'Disentangling Demand-Enhancing and Trade-Cost Effects of Maximum Residue Regulations', Economics Inquiry. 52, 1190-1203

Table 1: Schedule of EU Entry Price Control for Fresh Fruits and Vegetables and the Applicable Duties 


\begin{tabular}{llll}
\hline & Tomatoes & Oranges & Lemons $^{9}$ \\
\hline Application Date & $01.01-31.12$ & $01.12-31.05$ & $01.01-31.12$ \\
Mininum EP $(€ / 100 \mathrm{~kg})$ & 52.60 & 32.60 & 46.20 \\
Maximum EP $(€ / 100 \mathrm{~kg})$ & 112.60 & 35.4 & 55.8 \\
Specific EPDuties $(€ / 100 \mathrm{~kg})$ & $0-29.80$ & $0-7.10$ & $0-25.60$ \\
Highers EP duty $(€ / 100 \mathrm{~kg})$ & 29.80 & 7.10 & 25.60 \\
\hline
\end{tabular}

Source: European Commission, TARIC Database, 2014

Table 2: Detailed EPS Schedule for Tomato: 01.04 to 30.04

\begin{tabular}{lll}
\hline Cases & $\begin{array}{l}\text { EP Conditions for Different Import } \\
\text { Prices (MP) in Comparison with Entry } \\
\text { Prices }\end{array}$ & Entry Price Duties \\
\hline 1 & MP $\geq 112.60 \mathrm{EUR} / 100 \mathrm{~kg}$ & - \\
2 & $\mathrm{MP} \geq 110.30 \mathrm{EUR} / 100 \mathrm{~kg}$ & $2.30 \mathrm{EUR} / 100 \mathrm{~kg}$ \\
3 & $\mathrm{MP} \geq 108.10 \mathrm{EUR} / 100 \mathrm{~kg}$ & $4.50 \mathrm{EUR} / 100 \mathrm{~kg}$ \\
4 & $\mathrm{MP} \geq 105.80 \mathrm{EUR} / 100 \mathrm{~kg}$ & $6.80 \mathrm{EUR} / 100 \mathrm{~kg}$ \\
5 & $\mathrm{MP} \geq 103.60 \mathrm{EUR} / 100 \mathrm{~kg}$ & $9.00 \mathrm{EUR} / 100 \mathrm{~kg}$ \\
6 & $\mathrm{MP} \geq 0 \mathrm{EUR} / 100 \mathrm{~kg}$ & $29.80 \mathrm{EUR} / 100 \mathrm{~kg}$ \\
\hline
\end{tabular}

Source: EC TARIC, 2014

Table 3: Export Performance and Direction of Trade of Africa's Exports, 1995 to 2013

\begin{tabular}{lccc|lccc|lccc}
\hline \multicolumn{7}{c}{ Tomatoes } & \multicolumn{4}{c|}{ Oranges } & \multicolumn{4}{c}{ Lime \& Lemon } \\
\hline Main & 1995 & 1995 & 2008 & Main & 1995 & 1995 & 2008 & Main & 1995 & 1995 & 2008 \\
Importer & - & - & - & Importer & - & - & - & Importer & - & - & - \\
& 2013 & 2007 & 2013 & & 2013 & 2007 & 2013 & & 2013 & 2007 & 2013 \\
\hline Africa & 86.5 & 74.4 & 91.6 & Africa & 80.1 & 80.6 & 79.8 & Africa & 67.1 & 68.1 & 66.7 \\
EU & 7.7 & 9.4 & 2.9 & EU & 16.8 & 13.0 & 18.9 & EU & 24.8 & 18.9 & 27.4 \\
Jordan & 2.9 & 0.04 & 4.1 & Israel & 0.8 & 1.6 & 0.4 & Argentina & 4.1 & 8.6 & 2.2 \\
Syria & 1.3 & 3.8 & 0.2 & Australia & 0.6 & 1.6 & 0.01 & Israel & 0.8 & 0.6 & 0.9 \\
Others & 1.6 & 12.4 & 1.2 & Others & 1.7 & 3.2 & 0.89 & Others & 3.2 & 3.8 & 2.8 \\
Total & 100. & 100. & 100. & Total & 100. & 100. & 100. & Total & 100. & 100. & 100. \\
& 0 & 0 & 0 & & 0 & 0 & 0 & & 0 & 0 & 0 \\
\hline
\end{tabular}

Source: Calculation based on Data from UN COMTRADE

\footnotetext{
${ }^{9}$ EU entry price control only covers lemon but does not extend to lime.
} 
Table 4: Effects of EU Standards on Africa's Exports

\begin{tabular}{|c|c|c|c|}
\hline VARIABLES & Tomatoes & Lime and Lemon & Oranges \\
\hline \multirow[t]{2}{*}{ Exporters GDP } & 0.095 & $0.249 * *$ & 0.080 \\
\hline & $(0.095)$ & $(0.109)$ & $(0.090)$ \\
\hline \multirow[t]{2}{*}{ Importers GDP } & $0.260 *$ & $0.629 * * *$ & $0.572 * * *$ \\
\hline & $(0.134)$ & $(0.234)$ & $(0.128)$ \\
\hline \multirow[t]{2}{*}{ EU Pesticide Standards } & $6.004 * * *$ & $6.885 * * *$ & $4.012 * * *$ \\
\hline & $(1.509)$ & $(1.541)$ & $(1.224)$ \\
\hline \multirow[t]{2}{*}{ Initial Status } & $1.097 * * *$ & $0.546 * *$ & $0.554 * * *$ \\
\hline & $(0.252)$ & $(0.255)$ & $(0.193)$ \\
\hline \multirow[t]{2}{*}{ Distance } & $-3.898 * *$ & $-2.896 *$ & $-2.851 * * *$ \\
\hline & $(1.607)$ & $(1.554)$ & $(0.893)$ \\
\hline \multirow[t]{2}{*}{ Colony } & 0.170 & $2.876 * *$ & $1.637 * *$ \\
\hline & $(0.239)$ & $(1.153)$ & $(0.823)$ \\
\hline \multirow[t]{2}{*}{ Language } & $2.197 * * *$ & 1.028 & $2.867 * * *$ \\
\hline & $(0.698)$ & $(0.841)$ & $(0.684)$ \\
\hline \multirow[t]{2}{*}{ RTA } & 0.253 & 0.593 & $1.138 * *$ \\
\hline & $(0.568)$ & $(1.218)$ & $(0.495)$ \\
\hline \multirow[t]{2}{*}{ Constant } & $-12.23 * * *$ & $-26.34 * * *$ & $-19.29 * * *$ \\
\hline & $(3.805)$ & $(6.520)$ & $(4.235)$ \\
\hline Observations & 1,176 & 1,248 & 1,050 \\
\hline
\end{tabular}

Table 5: Effects of Entry Price Control on Africa's Exports

VARIABLES Tomatoes Lime and Lemon $\quad$ Oranges




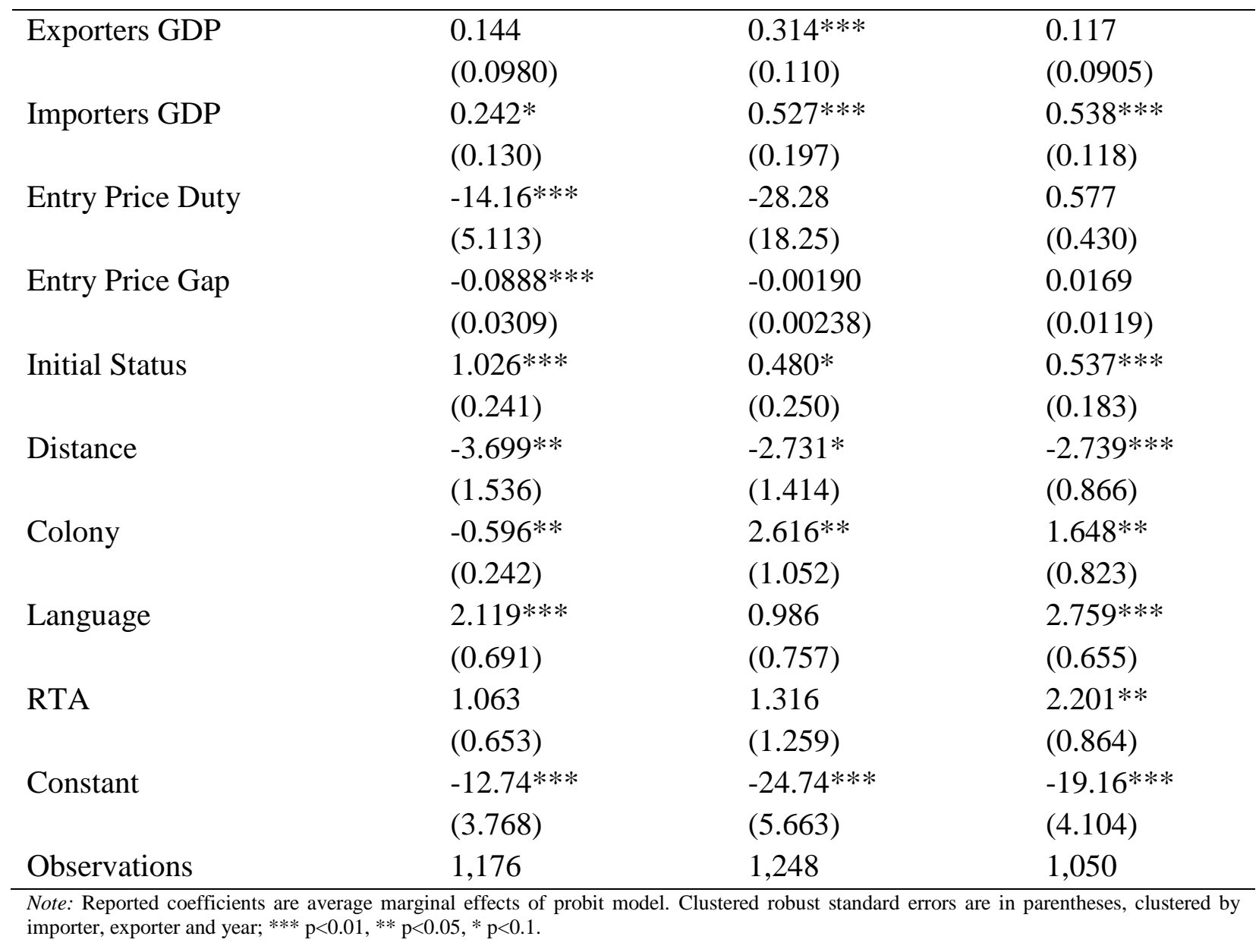

Table 6: Robustness Checks with an Alternative Sample: Eliminating Economically Small Export Flows 


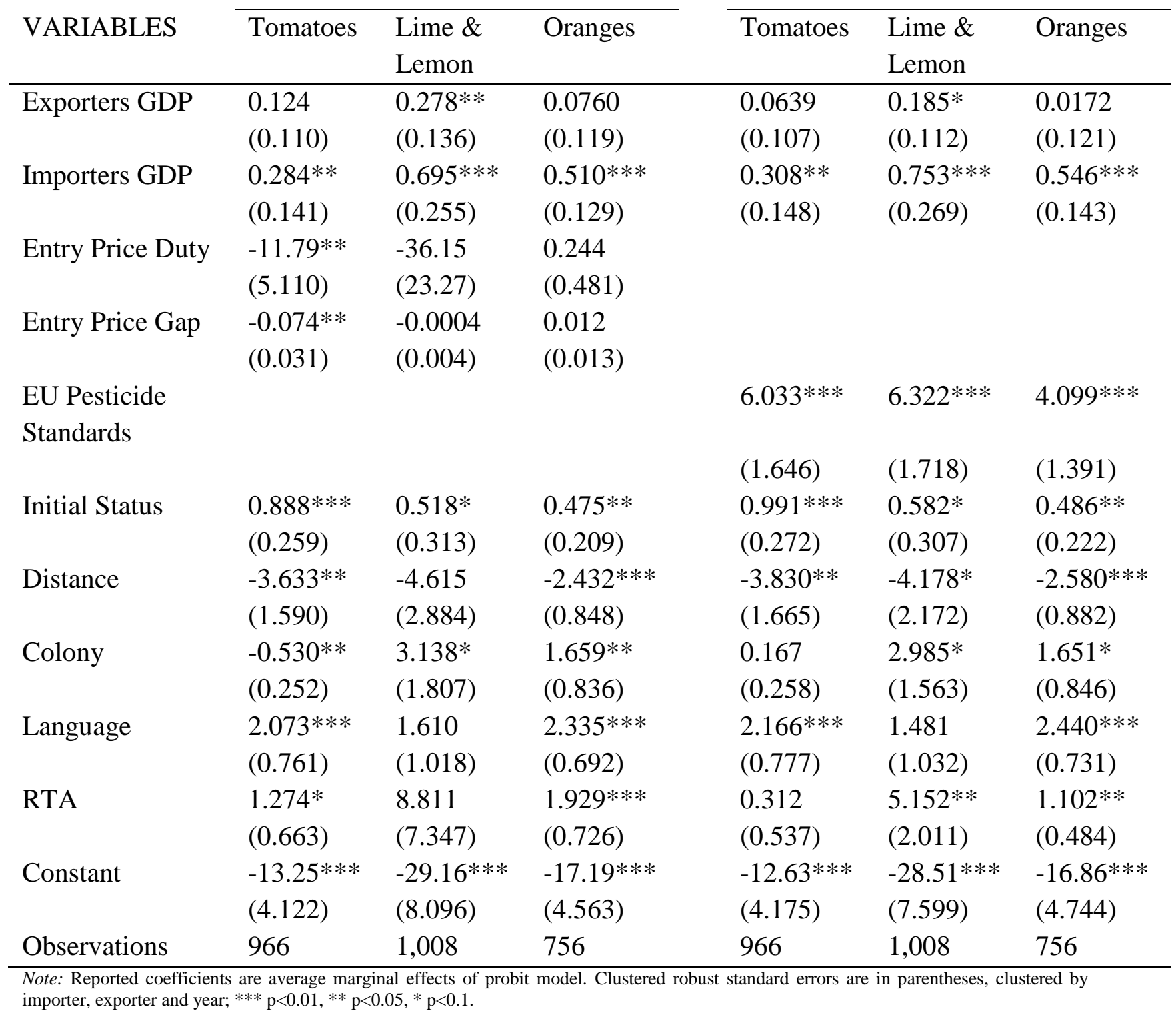

Table 7: Robustness Checks: Robust Checks: Sensitivity to Outliers

\begin{tabular}{|c|c|c|c|c|c|c|}
\hline \multirow[b]{2}{*}{ VARIABLES } & \multicolumn{3}{|c|}{ Entry Price System } & \multicolumn{3}{|c|}{ Food Safety Standards } \\
\hline & Tomatoes & $\begin{array}{l}\text { Lime \& } \\
\text { Lemon }\end{array}$ & Oranges & Tomatoes & $\begin{array}{l}\text { Lime \& } \\
\text { Lemon }\end{array}$ & Oranges \\
\hline \multirow[t]{2}{*}{ Exporters GDP } & 0.0759 & $0.313 * *$ & 0.132 & 0.0138 & $0.241^{*}$ & 0.0918 \\
\hline & $(0.0971)$ & $(0.128)$ & $(0.100)$ & $(0.0983)$ & $(0.127)$ & $(0.101)$ \\
\hline \multirow[t]{2}{*}{ Importers GDP } & $0.307 * *$ & $0.707 * * *$ & $0.549 * * *$ & $0.327 * *$ & $0.837 * * *$ & $0.584 * * *$ \\
\hline & $(0.134)$ & $(0.230)$ & $(0.121)$ & $(0.140)$ & $(0.272)$ & $(0.132)$ \\
\hline \multirow[t]{2}{*}{ Entry Price Duty } & $-14.45 * * *$ & -29.63 & 0.353 & & & \\
\hline & $(5.472)$ & $(18.52)$ & $(0.466)$ & & & \\
\hline \multirow[t]{2}{*}{ Entry Price Gap } & $-0.089 * * *$ & -0.002 & 0.011 & & & \\
\hline & $(0.033)$ & $(0.002)$ & $(0.0124)$ & & & \\
\hline
\end{tabular}




\begin{tabular}{|c|c|c|c|c|c|c|}
\hline \multirow{2}{*}{$\begin{array}{l}\text { EU Pesticide } \\
\text { Standards }\end{array}$} & & & & $5.742 * * *$ & $6.551 * * *$ & $3.727 * * *$ \\
\hline & & & & $(1.571)$ & $(1.572)$ & (1.294) \\
\hline \multirow[t]{2}{*}{ Initial Status } & $1.037 * * *$ & $0.460 *$ & $0.500 * * *$ & $1.096 * * *$ & $0.502 *$ & $0.507 * *$ \\
\hline & $(0.252)$ & $(0.259)$ & (0.189) & $(0.264)$ & $(0.263)$ & $(0.199)$ \\
\hline \multirow[t]{2}{*}{ Distance } & $-3.607 * *$ & $-2.406^{*}$ & $-2.777 * * *$ & $-3.827 * *$ & $-2.638 *$ & $-2.912 * * *$ \\
\hline & $(1.547)$ & $(1.425)$ & $(0.880)$ & $(1.657)$ & $(1.549)$ & $(0.908)$ \\
\hline \multirow[t]{2}{*}{ Colony } & $-0.585 * *$ & $2.287 * *$ & $2.059 * *$ & 0.137 & $2.471 * *$ & $2.072 * *$ \\
\hline & $(0.255)$ & (1.083) & $(0.851)$ & $(0.249)$ & (1.173) & $(0.855)$ \\
\hline \multirow[t]{2}{*}{ Language } & $2.221 * * *$ & 1.216 & $2.526 * * *$ & $2.308 * * *$ & 1.344 & $2.613 * * *$ \\
\hline & $(0.703)$ & $(0.803)$ & $(0.661)$ & $(0.718)$ & $(0.873)$ & $(0.691)$ \\
\hline \multirow[t]{2}{*}{ RTA } & 0.909 & 1.294 & $2.123 * *$ & 0.292 & 0.650 & $1.244 * *$ \\
\hline & $(0.601)$ & $(1.317)$ & $(0.838)$ & $(0.570)$ & (1.249) & $(0.530)$ \\
\hline \multirow[t]{2}{*}{ Constant } & $-12.86 * * *$ & $-29.54 * * *$ & $-19.78 * * *$ & $-12.13 * * *$ & $-31.73 * * *$ & $-19.86 * * *$ \\
\hline & $(3.874)$ & $(6.820)$ & $(4.187)$ & (3.997) & (7.792) & $(4.324)$ \\
\hline Observations & 1,092 & 1,152 & 966 & 1,092 & 1,152 & 966 \\
\hline
\end{tabular}

Table 8: Robustness Check: Endogeneity of Pesticide Standards

\begin{tabular}{|c|c|c|c|}
\hline Variables & Tomatoes & Lime and Lemons & Oranges \\
\hline \multirow[t]{2}{*}{ Exporters GDP } & 0.0999 & $0.316 * * *$ & 0.0829 \\
\hline & $(0.0972)$ & $(0.118)$ & $(0.0979)$ \\
\hline \multirow[t]{2}{*}{ Importers GDP } & $0.242 *$ & $0.607 * * *$ & $0.551 * * *$ \\
\hline & $(0.137)$ & $(0.225)$ & $(0.131)$ \\
\hline \multirow{2}{*}{ EU Pesticide Standards ${ }_{t-1}$} & $4.697 * * *$ & $4.530 * * *$ & $2.240^{*}$ \\
\hline & $(1.341)$ & $(1.602)$ & $(1.314)$ \\
\hline \multirow[t]{2}{*}{ Initial Status } & 0.320 & -0.470 & -0.0241 \\
\hline & $(0.253)$ & $(0.374)$ & $(0.237)$ \\
\hline \multirow[t]{2}{*}{ Distance } & $-4.270 * *$ & $-3.411 *$ & $-2.911 * * *$ \\
\hline & $(1.663)$ & $(2.041)$ & $(0.876)$ \\
\hline \multirow[t]{2}{*}{ Colony } & -0.147 & $2.842 * *$ & $1.976 * *$ \\
\hline & $(0.246)$ & $(1.159)$ & $(0.844)$ \\
\hline \multirow[t]{2}{*}{ Language } & $2.212 * * *$ & 1.075 & $2.557 * * *$ \\
\hline & $(0.690)$ & $(0.841)$ & $(0.683)$ \\
\hline \multirow[t]{2}{*}{ RTA } & -4.670 & 1.539 & 4.330 \\
\hline & $(3.844)$ & $(1.533)$ & $(5.996)$ \\
\hline \multirow[t]{2}{*}{ Constant } & $-11.50 * * *$ & $-27.04 * * *$ & $-18.58 * * *$ \\
\hline & $(3.792)$ & $(6.519)$ & $(4.249)$ \\
\hline Observations & 980 & 1,040 & 805 \\
\hline
\end{tabular}

Note: Reported coefficients are average marginal effects of probit model. Clustered robust standard errors are in parentheses, clustered by importer, exporter and year; $* * * \mathrm{p}<0.01, * * \mathrm{p}<0.05, * \mathrm{p}<0.1$.

Appendix

Table A1: List of Countries in the Tomato Dataset 
Importers (EU) Belgium, France, Germany, Luxembourg, Netherlands, Portugal, Spain

Exporters (Africa) Algeria, Angola, Cape Verde, Comoros, Democratic Republic of Congo, Côte d'Ivoire, Egypt Arab Republic, Equatorial Guinea, Gabon, The Gambia, Ghana, Guinea-Bissau, Kenya, Liberia, Mauritania, Morocco, Nigeria, Sao Tome and Principe, Senegal, Sierra Leone, South Africa, Togo.

Table A2: List of Countries in the Lime and Lemon Dataset

Country Groups Members

Importers (EU) $\quad$ France, Italy, Luxembourg, Netherlands, Poland, Portugal, Spain

Exporters (Africa) Algeria, Angola, Benin, Cape Verde, Congo Republic, Côte d'Ivoire, Djibouti, Equatorial Guinea, Gabon, Ghana, Liberia, Madagascar, Mauritania, Morocco, Nigeria, Sao Tome and Principe, Senegal, Sierra Leone, South Africa

Table A3: List of Countries in the Oranges Dataset

Country Groups Members

Importers (EU) Belgium, France, Italy, Malta, Netherlands, Portugal, Spain

Exporters (Africa) Algeria, Angola, Benin, Cape Verde, Chad, Democratic Republic of Congo, Congo Republic, Côte d'Ivoire, Egypt Arab Republic, Equatorial Guinea, Gabon, The Gambia, Ghana, Guinea-Bissau, Liberia, Madagascar, Mali, Mauritania, Morocco, Nigeria, Sao Tome and Principe, Senegal, Sierra Leone, South Africa, Togo. 